\title{
130th anniversary of Prof. Dr. Vladimir Markov
}

\author{
Prof. Ivan Mitov, MD, PhD, \\ Dept. Medical Microbiology, Medical Faculty \\ Medical University of Sofia
}

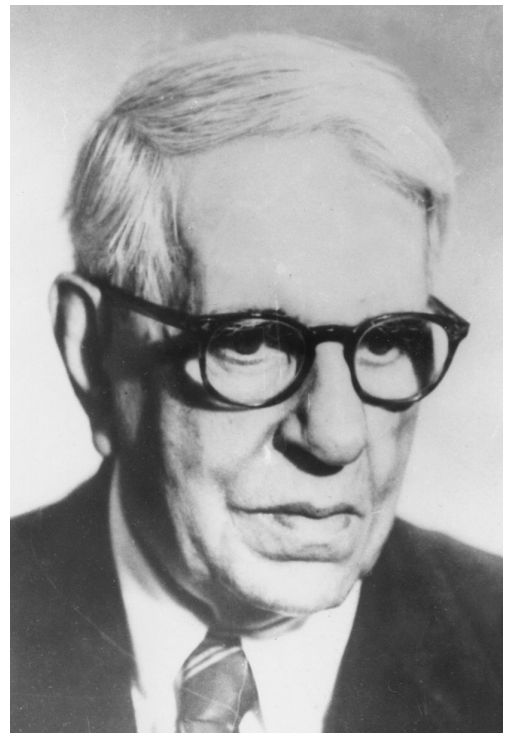

Prof. Dr. Vladimir Markov

This year marks 130 years since the birth of the founder and leader (untill 1958) of the Department of Microbiology at the Medical University Sofia in Bulgaria, the eminent and internationally recognized scholar Prof. Dr. VLADIMIR NESTOROV MARKOV, Full Member of the Bulgarian Academy of Sciences (Academician).

A contemporary with the liberation from Ottoman rule, Vladimir Markov was assigned by fate to become the father of microbiology in Bulgaria and creator of the national microbiological school. He elevated national microbiology to world-class level at that time, leaving a profound legacy in the development of medicine in Bulgaria.
Born in the city of Veliko Tarnovo, Vladimir Markov was brought up in a family of patriotic Bulgarians. His father Nestor Markov was an active participant in the struggle for spiritual and political liberation. His brother Marko Markov was a member of the detachment of Yane Sandanski and was killed in a battle of the liberation of Macedonia.

Vladimir Markov completed his secondary education in the state agricultural school "Obraztzov Chiflik" in Rousse. In 1904, he went to Germany, where he graduated in veterinary medicine in Munich and Berlin. Upon his return to Bulgaria, Vladimir Markov embarked on a career as a veterinarian doctor in Panagiurishte and Oriahovo. In lieu of his excellent training in veterinary medicine and by using bacteriological methods of investigation, he discovered the cause of infectious pneumonia in calves in the Kabuik horse farm near Shumen and provided science-based treatment for successful eradication of that epizootic. This investigative discovery brought to the forefront his special interest and specific talent for bacteriology as well as his ability to illuminate a purely practical question. This led to him devoting his first scientific work in 1909 to this subject.

Vladimir Markov's qualities were noticed by his colleagues and his superiors and in the autumn of 1909 , after successful competitive examination, he was sent to specialize in bacteriology and serology in Munich and Berlin. He worked in various research institutes including the Institute for Infectious Diseases "Robert Koch". Vladimir Markov received excellent microbiological training by prominent scholars such as T. Kit, P. Ulenhut, A. Wasserman, W. Loeffler and others. In 1911 he was promoted to a doctor of veterinary medicine at 
the University of Berlin.

After his return from Germany, Vladimir Markov was much sought after as a specialist in microbiology and in the course of six years he consecutively worked in the Veterinary Bacteriological Station and the Hygiene Institute of Sofia. During the Balkan Wars and the First World War he held key positions on various fronts as bacteriologist and set-up new laboratories and work stations. He examined the etiology of some vague but typical human and animal diseases and successfully battled cholera, dysentery, typhus and other diseases spread among the troops and the civilian population. $\mathrm{He}$ gave scientific significance to his practical experience with a number of publications recognized in the scientific literature both abroad and in Bulgaria, which defined him as an established researcher in the late twenties. On these grounds, after the establishment of the Medical Faculty of Sofia, Vladimir Markov was invited to be a chief assistant at first, and shortly after, in the middle of 1921 was elected private associate professor and head of the department of bacteriology and serology. He remained in this position for over four decades.

Vladimir Markov began his teaching activities with an interesting introductory lecture and discourse on "Agglutination as colloidal reaction" in October 1921. Among others he lectured and organized practical training in microbiology for medical students, agronomists, chemists, pharmacists and biologists till the end of his life. He developed and delivered the first lecture course in technical microbiology in the new found State Polytechnic school. All specialists in microbiology were trained and developed under his leadership. His lectures were full of content and real-life examples and together with his rich experience and originality, they aroused great interest. Looking very harsh and inaccessible on the outside, Vladimir Markov loved his students very much. He engaged with them on many levels and he had discussions with them on various professional, current and political issues. He sympathized with the progressive studentship and cultivated in his students the love for microbiology and science in general, and the selfless and enthusiastic service to the people. Vladimir Markov's students remember him encouraging them to participate in the student's movements in 1932 against the antidemocratic government.

Vladimir Markov's great love and dedication to the preparation of students consisted also of his constant efforts to provide them with textbooks and training aids. Vladimir Markov wrote more than ten original textbooks, manuals and other materials on microbiology for students of various disciplines at Sofia University.

Vladimir Markov established and maintained an original style, method and traditions in the teaching of microbiology. He actively contributed to the creation of new departments of microbiology at Sofia University and other universities that were opened in the years after World War II, as well as in the Sanitary and Epidemiological stations and the scientific-research institutes. Naturally those institutions became followers of his work, developing it further under the new conditions after the war.

As a scientist with an alert public awareness, Vladimir Markov was closely linked to prominent public figures. His closest friends were Prof. As. Zlatarov, Prof. As. Hadzhiolov, Academician Georgi Uzunov, Dr. Racho Angelov, who were brought together by long-term collaborative work in professional and social areas.

"Microbes in the service of life"- that was the motto of Vladimir Markov, left to his followers. This is one of the factors that can explain why till the end of his days Vladimir Markov associated his entire scientific and research work with the needs of society. He and his department were the team that developed and organized the microbiological thought and microbiologists all over the country, and in 1923 Vladimir Markov initiated the establishment of Bulgarian microbiological society, which he chaired till the end of his life in 1962.

There is hardly any field in microbiology to which Vladimir Markov did not contribute scientifically. The scientific heritage left by Vladimir Markov is outstanding. For 53 years, he worked dedicatedly, strenuously and enthusiastically, with the expertise of a true scientistexperimentalist-bacteriologist. He wrote more than 180 works devoted to general microbiology, infectiology, infection and immunity, serology, special microbiology, industrial and soil microbiology, food microbiology, etc. He was highly appreciated and quoted as early as the 1920s in many German essays, textbooks and magazines and was placed on a par with all most prominent German researchers.

Vladimir Markov's achievements on the problems of variability of microorganisms should be noted among his most important scientific developments. Regarding the discussions that occurred at the beginning of the century on the problems of variability, Vladimir Markov in 1922, for the first time in science, founded and described the dissociation in the anthrax bacillus later 
called 8 IK forms of bacteria, and proved the possibility of existence of naturally attenuated forms, named by him "vaccine in nature". This discovery has not lost its theoretical and practical significance to the present day. He explained experimentally the phenomena paraagglutination as a result of mixed infection in which bacteria of the saprophytic intestinal flora acquire some properties of the pathogenic intestinal microbes. The formulations of his experiments on para-agglutination were adopted and then used for decades in science and references. These studies of Vladimir Markov significantly contributed to the explanation of the origin of the so-called atypical forms of bacteria which is very important for microbiological diagnosis. Vladimir Markov defended his science-based views on the problems of variability with the dignity of a scholar. Even in the politically laden period of 1948-1950 he rejected the theory of some politically supported pseudo-scientists about the possible conversion of microbial species from one into another, which was attributed by the ruling party as his great sin.

Vladimir Markov devoted a lot of effort to the study of etiology and epidemiology of many bacterial, viral and parasitic diseases in humans and domestic animals. He identified the cause agents of typhoid Borreha recurrence, on piroplasmosis in domestic animals, found in Bulgaria for the first time in 1912 as well as the cause agents of typhus, anaerobic infections, etc. He discovered the non-described, till then anaerobic bacillus, and gave it the name of Bacillus anaerobus hemoliticus.

We should also recall the incredibly active research and practical work of Vladimir Markov in the fight against intestinal infections. He studied the large epidemic of typhoid fever in Sofia (1932), Kyustendil (1938-1939), a number of toxico-infectious outbreaks, most important among which were the poisoning with foods, bonito fish, cheese, the dysentery epidemic in Svishtov, diseases of glanders, anthrax, rhinoscleroma and others. Vladimir Markov was the first in our country back in 1954 to point out the task and manage extensive research on proving the presence of enteropathogenic bacteria coli in our bodies and its importance for pathology.

In his studies on the biology of both pathogenic and beneficial microbes to man, Vladimir Markov created a number of more comprehensive elective nutrient media to facilitate cultivation and microbiological diagnosis.

Early in his scientific quest Vladimir Markov was interested in the problems of the process of infection, immunity and serology. In 1911 he was the first to develop cell-free extracts of anti-anthrax precipitating serum and studied the bactericidal action of normal serum on bacteria. His theory concerning the antibodies analyzed in his work "Antibodies and sub-antibodies" published in 1928, as well as his works on obtaining specific sera against streptococcus, diphtheria bacteria and others were valued as highly original. In addition, the combined active and passive immunization against rabies was a method developed by Vladimir Markov and remains of great importance even today for the successful control of this extremely dangerous infection.

The biochemical studies of Vladimir Markov related to the natural cycle of substances and the role of microorganisms contributed theoretically to the studies of oceanography, balneology and toxicology. Such are his publications devoted to biochemical microbiological processes in the formation of the therapeutic mud in the cities of Pomorie and Tuzlata as well.

Within the context of the industrial microbiology Vladimir Markov also contributed greatly to development in Bulgaria. His scientific research helped support industrial production and was used in the making of valuable manufactured goods, food, beverages, etc. His studies from 1923 on the optimization of the wine producing process by introducing pure cultures of selected yeasts became very popular. He provided those to the interested wine-makers for free till the creation of specialized institutes and laboratories in 1950.

Based on his studies, Vladimir Markov gave the breadmaking industry a pure culture of bread yeast and his own original method for detecting tampering with hop yeast bread. This helped improve the quality of bread and facilitated workers in the bread making process. During the hungry years of the Second World War, his research into mold bread resulted in the preparation of bread yeast of lactic acid bacteria for the production of potato bread.

He conducted extensive research on the problem of nitrogen fixation and on the use of organic fertilizers with his chemical "Radiksoya"-a problem that has not lost its importance today. He carried out comprehensive and in-depth studies on "Bacterial flora in Bulgarian yogurt, plain Bulgarian cheese, sheep's milk and rennet". Asked for assistance by soap manufacturers whose export shipments were returned as unfit, Vladimir Markov explored the causes, described two new types of bacteria, called Serratia saponaria I and II, studied their biochemical 
characteristics and proposed measures to prevent rancidity of the soap.

The issues of antibiotics interested Vladimir Markov in many aspects and his theoretical and practical work on "volatile antibiotics", affecting bacteria from a distance, provoked great interest as well. He and Prof. Sv. Bardarov together examined the resistance to penicillin, developed and proposed the neutralization of the enzyme and recovery of the efficiency of the antibiotic during treatment with anti-penicillinase serum.

According to his understanding of the infectious process in the fifties, Vladimir Markov developed the hypothesis for the viral genesis of tumors, whereby the virus and the cell produced organically bound complex which is foreign to the body. Moreover, the emergence of this complex was determined by a number of exogenous and endogenous factors, a pattern characterizing the infectious process.

In his promotional activities he managed different levels of involvement. Vladimir Markov pointed out the great importance of the control of infectious diseases, of women and their role in public life, of alcoholism and the fight against it. A great patriot and admirer of Bulgaria, he described its beauty and passionately promoted tourism and sports. The ultimate goal of his activity was to help people to "master the art of living" and devoted more than 250 works to these causes.

Vladimir Markov, the great scientist and doctor was also a great fighter for peace. As a scientist, microbiologist and a public figure he was not afraid to protest angrily against the preparation of bacteriological warfare in the mid-thirties. In a brochure issued by him, he condemned the supporters and scientists who were developing those weapons of mass extermination. Academician Vladimir Markov led the battle against the bacteriological weapons till the end of his life. His creed on the problems of life, peace and war he expressed as follows: "Progress and culture are created only in an environment of peace".

This is a brief summary of the creative scientific activity of Vladimir Markov. What he had mastered and created in science, he readily and with dedication shared in the press, in magazines, in the media, in lectures and discussions at a variety of forums. He also contributed to various Bulgarian and foreign magazines. $\mathrm{He}$ was an editor-in-chief in some of them. In the years after World War II, Vladimir Markov's qualities as a skilled scientist and academic supervisor were well founded and he established the national school of medical microbiology, which even today enjoys recognition.

Vladimir Markov's scientific achievements were recognized when he was elected a Full Member of the Academy of Sciences (Academician) and Doctor Honoris Causa of the Faculty of Medicine at the University of Sofia. He was also awarded the prestigious "Dimitrov Prize", the title of "Distinguished doctor", the medals "Red Flag", "People's Republic of Bulgaria grade II". His life and work at the Department of Microbiology for the Medical Faculty of the University of Sofia and as founder of microbiology in Bulgaria, Academician Prof. Dr. Vladimir Nestorov Markov remains an epic model and example in the history of medicine in Bulgaria.

\section{SELECTED REFERENCES ${ }^{1}$}

Markov, Wl., Studien ueber die Variability der Bakterien. Zugleich ein Beitrag zur Morphologie und Biologie des Milzbrand-bazillus, Ztschr. f. Infektionskrankh., parasiL Krankh. u. Hyg. d. Haustiere, Bd. 12, 1912, 137158.

Bernhardt, G., W. Markoff., Ueber Modifikationen bei Bakterien. Beitrag zur Frage der sogenannten "Mutation" bei Bakterien. - Ztrbl. f. Bakteriol. etc., I Abt., Orig., Bd. 65, 1912, 1-4.

Markov, Wl., Experimentelle Studien ueber das Wesen der Para-agglutination, Ztrbl. f. Bakteriol. etc., I Abt., Orig.Bd. 75, 1916, 372-383.

Gildenmeister, E., Markoff, Wladimir N. Experimentelle Studien ueber das Wesen der Panagglutination. I. Mitteilung. (C. f. Bakt., I Abt., Orig., Bd. 78, 1916, p. 372), Ztrbl. f. Bakteriol. etc., I Abt., Ref., Bd. 66, 1918, H. 19, p. 489.

Markov, Wl., Spezifische und subspezifische Antikorper. Wirkung von Bakteriophagen auf bakterielle Antigene und Kompleentbindungsversuche, Ztschr. f. Immunforsch., Bd. 56, 1928, 95-106.

Markov, Wl., Z. K. Jatschewa. Eine todliche Episootie unter den Forellen im Mussalahsee, Ztrbl. f. Bakteriol. etc., II Abt. Orig., Bd. 100, 1939, 194-201.

Markov, Wl., Zum Problem der Seefischfaulnis, Ztrbl. f. Bakteriol. etc., II Abt, Orig, Bd. 101, 1939, 151-171.

Gildemeister, E., Markoff, Wl. N., Zum Problem der Seefischfaulnis. (Ztrbl. f. Bakter., 11, Orig, 101, 151171, 1939), Ztrbl. f. Bakteriol. etc., I Abt., Ref., Bd. 137, 1940, 1/2, p. 44.

\footnotetext{
${ }^{1}$ For a full bibliography see: Markov, K., V. Valchanov, Vladimir Markov-Bibliography, in: Bibliography of Bulgarian scientists, Bulgarian Academy of Sciences Publ. House, 1960, p. 201.
} 
Gaethgens, W., Markoff, Wl. N., Erfahrungen mit dem Behringschen Diphtherieheilserum in Bulgarien. ( $Z$. Immunforsch., 99, 27-39, 1940), Ztrbl. f. Bakteriol. etc., I Abt., Ref., Bd. 140, 1941, 1/2, p. 12.

Markov, Wl., Die Menge der antitoxischen Einheiten (AE) bei der Behandlung der toxischen Diphtherie, Wiener med. Wschr., Bd. 91, 1941, 14, 279-280.

Markoff, W. N., Die Menge der antitoxischen Einheiten (AE) bei der Behandlung der toxischen Diphtherie. (Wien. med. Wschr., 1941, 279-281), Ztrbl. f. Bakteriol. etc., I Abt., Ref., Bd. 140, 1941, 21/22, p. 445.

Markov, Wl., Die Verbeugung der Garungsdyspepsie, Wiener med. Wschr., Bd. 92, 1942, 20, p. 1-2.
Markov, W., The Normal Intestinal Flora in Man. Annales Medicales, Revue de l'Union des Medicins Bulgares, Sofia, 1948,40/10 (1174-1180). Excerpta Medica, Sect. IV, Medical Microbiology and Hvgiene, vol. II, 1949, 10, Abstr. 4947.

Markov, Wl., Serratia saponaria I und II. Schadliche Bakterien in der Seife, Ztrabl. f. Bakteriol. etc., I Abt., Orig. Bd. 110, 1956, 26-31.

Markov, Wl., G. Mitov, G. Saev. Die Eigenschaften der biogenen Substituenten der fluchtigen Antibiotika und ihre Verbreitung. Zentralblatt fur Baktertologie, Parasitenkunde, Infektlonskrankheiten und Hygiene, I Orig. 173. 129-140 (1958). 